\title{
Teresa Kovacs
}

\section{Disturbance in the Intermediate}

\section{Secondary Drama as a Parasite}

Elfriede Jelinek's essay (for a reprint see this volume: 337-338) describes a concept that can be viewed as a form of editing, that, however, extends well beyond parody, contrafactum, travesty, etc. ${ }^{1}$ What Jelinek calls for with the "genre" of secondary drama she introduced, cannot be referred to as a counter-song or a sequel; her concept is about concurrence, about making two texts simultaneously present in the moment of staging, as suggested by the characterization of secondary drama as an accompanying drama (Begleitdrama). By this requirement, Jelinek intervenes in the theatre business more extensively than texts usually do, thus continuing to question its historical and present conditions, a constitutive principle of her dramatic work (Haß and Meister 2015: 113-114). Jelinek associates two of her theatre texts with secondary drama: Abraumhalde (2009), created as a secondary drama to Gotthold Ephraim Lessing's Nathan der Weise, as well as FaustIn and out (2011) that cites Goethe's Urfaust as the central referential text. Formulated in this essay, the instruction to stage the plays only along with Lessing's and Goethe's dramas respectively was at first actually enforced by Jelinek's publishing house. Both premieres thus chose a form, in which primary ${ }^{2}$ and secondary dramas were connected, and yet showing very different approaches at the same time. ${ }^{3}$

Notes on Secondary Drama (Anmerkung zum Sekundärdrama) has to be seen in the context of the much-debated issue concerning the progressing economisation of public theatre. In the first sentence of the text, Jelinek links aesthetic considerations primarily to economic conditions and presents the secondary drama

1 Jelinek (2010) published Anmerkung zum Sekundärdrama on November 18, 2018 on her website. It has since been reprinted repeatedly in programme booklets for productions of secondary dramas.

2 This too is a term the author introduced (Behrendt 2013).

3 Abraumhalde (Mining Dump) was integrated in Nathan der Weise (Nathan the Wise) by Nicolas Stemann as part of his new staging in the Thalia Theater in Hamburg in the form of an interruption (premiere: October 3, 2009). The director Dušan David Pařizek premiered Jelinek’s FaustIn and out together with Goethe's Faust I (combined with quotations from Faust II) under the title Faust 1-3 in the Schauspielhaus Zürich (premiere: March 8, 2012). Goethe's Faust was initially seen on the big stage of the Schauspielhaus while Jelinek's secondary drama was staged in a soundproof music room in the basement of the building. In the last third, the production from the basement was merged with Goethe on the main stage. 
ironically as a well sellable, innovative form. Alone the context of the essay's origin makes it clear that Jelinek's reflections aim at a critical questioning of the economic conditions of theatre. The first version of this essay emerged as a response to the question regarding whether Jelinek thinks of herself as an artist, given the neoliberal trends in cultural activities. Jelinek's response was published under the title Reichhaltiger Angebotskatalog in the June 2009 issue of the Theater heute magazine (N.N. 2009).

In addition, the essay comments on the current debate about the so-called postdramatic theatre or Regietheater (director's theatre), which have been increasingly accused of having developed a peculiar affinity to neoliberalism, of reproducing their concepts of work and production and thus forfeiting the potential to reflect critically and undermine subversively these concepts (Stegemann 2014; Jürs-Munby and Pelka 2015: 17-32). Confronting the aesthetics of postdramatic theatre and Regietheater, authors such as Peter Handke, Daniel Kehlmann, and Peter Turrini have been levelling criticism for several years, partly in general, partly directly at Jelinek's textual form, demanding a return to realism, to the historical category of drama and therefore to dialogue, plot, and character (Kehlmann 2011, Turrini 2011). Jelinek responded repeatedly to the rejections she had to cope with due to her specific text-form: for instance, quite decidedly in Grußwort nach Japan where she confronts the rhizomatic structure of her texts with the eighteenth-century dramatic form:

The notion of text surface is now frowned upon in Europe, at least in the German-speaking countries, for it means: boredom. Nothing happens. No interesting stage figures playing with and against each other. We would prefer a juicy life on stage! My bamboo also wants its juicy life and it takes it easy: it is beneficial to watch it spring up, even if it can get extremely annoying, threatening to harass the pond liner and the dear goldfish. My plays also grow, I don’t know who benefits from that and how. (Jelinek 2012)

Secondary drama can be seen as part of this critical debate; it responds to the discussions about the distinction between dramatic, pre-, post- and again-dramatic theatre texts ${ }^{4}$ by identifying such distinctions as problematic, undermining them and making them eventually impossible.

4 Lehmann introduced the terms pre-dramatic and post-dramatic in his 1991 study Theater und Mythos (Theatre and Myth) based on Andrzej Wirth, pointing to the fact that plays of Greek antiquity and contemporary theatre texts resemble each other in their variety of forms, while drama as a historical category has established itself since the Renaissance and follows another, very specific understanding of theatre and theatre text, in which dialogue and acting subjects are central. (Lehmann 1991: 6) With the concept of post dramatic theatre having gained acceptance as a categorization of all those theatre texts that do not correspond to the dramatic form 
The considerations mentioned in the present essay thus cannot be viewed in isolation from Jelinek's other reflections on theatre aesthetics. Since her first play Was geschah, nachdem Nora ihren Mann verlassen hatte oder Stützen der Gesellschaften (1979), ${ }^{5}$ her writing has followed the intention of arousing, disturbing, and destroying the representation theatre and the bourgeois dramatic form of the eighteenth century. Jelinek's early texts actually dealt with the destruction of established forms, which one of her most important essays on theatre aesthetics also points out, saying: "Ich schlage sozusagen mit der Axt drein, damit kein Gras mehr wächst, wo meine Figuren hingetreten sind." ${ }^{6}$ Throughout her work with theatre texts, however, the critical analysis of dramatic conventions, with a simultaneous inscription within the dramatic tradition, was becoming more and more important. This is proved, for instance, by the play Ulrike Maria Stuart (2006) that uses Schiller's Maria Stuart as its background by picking up on the metrical language while constantly demolishing it with Jelinek's peculiar Textflächen (text surfaces). The author herself declares her intention to "force her way" ("hineindrängen") into Schiller's tragedy with Ulrike Maria Stuart, "nicht um sie zu etwas andrem aufzublasen wie einen armen Frosch, der dann platzt, sondern um mein eigenes Sprechen in diese ohnehin schon bis zum Bersten vollen Textkörper der beiden Großen Frauen, dieser Protagonistinnen, auch noch hineinzulegen." "The principle of addition and parasitic invasion in what already exists is being continued and enhanced through the concept of secondary drama, namely by implementing the process of invading in the moment of staging and making it comprehensible for the audience. The complexity of the relationship between critical negation and productive appropriation becomes eventually intentional in formulations such as "viking-ize" ("Aufnorden") and "bleach them blond" ("Blondieren") of the classics or in the description of the way secondary drama works, defined by Jelinek as a down pillow used to hit the marble blocks Lessing and Goethe with who stand at the top of the German-language literary canon (Jelinek and Koberg 2012). All this emphasizes the fact, that it is simply

(following the 1999 publication of Lehmann's eponymous book), the notion of again-dramatic theatre is often used in current research on more recent plays in order to describe a turn towards the dramatic form among young generation of authors (Tigges 2008).

5 This text uses two Henrik Ibsen's plays as its basis: Nora oder Ein Puppenheim (1879) and Stützen der Gesellschaft (1877).

6 "I swing the axe, as it were, so that no grass grows there where my characters appeared." (Jelinek 1984: 14).

7 "not to inflate it into something else like a poor frog, which then bursts, but to insert my own speech in the textual bodies (full to the bursting point already) of the two great women, the protagonists." (Jelinek 2005: 12). 
not the destruction of tradition, but an arousal and disturbance that should help establish a new perception of the dramas.

The aesthetics of disturbance Jelinek pursues with her secondary drama concerns both the dramatic texts themselves, their content and form, as well as the larger system of literary and theatre business (Kovacs 2016). It is therefore the issues of incest, domestic and systemic violence, and totalitarianism that make Jelinek's secondary dramas visible as a repressed side of the primary dramas, linking them to the values of the Enlightenment such as freedom, tolerance, and equality. It becomes clear that all these idealistic demands are to be understood as forms of inclusion and exclusion, that the community of enlightened citizens implies the exclusion of women, of the economically and socially less well-off, of minorities and foreigners, etc. The dramatic form is unmasked as a construct which contributed heavily to these exclusions by remaining reserved, as a royal genre, for white men for a long time. Jelinek also criticizes drama in connection to the concept of genius, which emerged in the eighteenth century, resulting in the far-reaching exclusion of women from literary production. She compares, for instance, the demands for originality, authenticity, uniqueness, and durability, associated with the equation of artists with geniuses, with the idea of quoting and that what is not authentic, elevating transience to a constitutive feature of secondary drama. Emphasizing the lack of understanding of the classics also reminds of the cult of genius, namely of the deliberate misreading and slaying of the father's generation and tradition to make room for something entirely innovative (Schabert and Schaff 1994: 12). Last but not least, the reference to Shakespeare's singular position problematizes the orientation of German-language protagonists of the Sturm und Drang movement to this author, as is evident, for instance, in Goethe's speech Zum Schäkespears Tag. In the context of secondary drama, Jelinek also refers to Schleef and adds his critical examination of the reception of Shakespeare to her concept: Schleef links this reception with the exclusion of women from the tragic conflict in the German classical period (Schleef 1997: 10). With the ironic subordination, however, secondary drama also points to the hierarchies associated with the act of canonization and establishing of classics. By means of conscious engagement in the theatre business, the whole concept responds to questions of repertoire and programming. It points out to the fact that canonized texts continue to be played on the main stages of state theatres whereas new and experimental texts are assigned to smaller stages. ${ }^{8}$ Furthermore, by emphasizing a woman perspective,

8 The statistics of the German Stage Association for the seasons 1990/91 to 2012/13 show that Jelinek's "ironic" gesture of dependence on the "classics" is not that ironic, considering the fre- 
the concept displays the gender gap that is still more noticeable in theatre than in other areas. ${ }^{9}$

Building upon Michel Serres's study Le Parasite (1980), Jelinek's concept can be described as a parasitic, disruptive element, clamping two texts and systems and thus creating interfaces to attach itself to and cause irritations by processes of fragmentation and interruption, inversion and non-hierarchy, creation of ambivalence, polyphony and self-reflexivity (Serres 1982). The term secondary drama itself gives rise to a disturbing noise that includes all the constituent elements of the concept: establishing a binary dichotomy of secondariness and drama, it creates an uncertainty which remains unresolved and thus leads to a replacement of either-or with both-and or neither-nor. Using the term drama, Jelinek cites exactly that historical category that her theatrical texts do not correspond to: they formally resemble prose and are, in research, also categorized as postdramatic (Lehmann) or no-longer-dramatic (Poschmann) theatre texts. With the notion of secondariness, she introduces a term which, following Szondi's central definition of drama, opposes the drama irreconcilably:

[T] he Drama is primary. It is not a (secondary) representation of something else (primary); it presents itself, is itself. [...] The Drama has no more room for quotation than it does for variation. Such quotation would imply that the Drama referred to whatever was quoted. Variation would call into question the Drama's quality of being primary ("true”) and present it as secondary (as a variation of something and as one variation among many). (Szondi 1983: 196)

In this uncertainty, the generic term opens up an interspace where seemingly fixed categories like drama and secondary become negotiable again. Secondary drama counteracts the fact that the form becomes transparent in favor of the content and, through the generic term, focuses attention to the question as to what is meant by drama and by the concept of secondariness or how the relation between these categories would be thinkable. With the secondary dramas penetrating very specific plays that are at the forefront of the German literary canon, they get to the bottom of established expectations and habits of perception of the spectators in order to evoke a feeling of alienation when the secondary drama bursts in, a feeling that also or directly applies to these seemingly well-known dramas. In the combination of primary and secondary drama, there is a mutual

quency of productions and the number of visitors which demonstrate the singular position of Lessing, Goethe and Schiller (Deutscher Bühnenverein 1990-2013).

9 This can be seen, for instance, in the Goethe Institute list of fifty currently most important directors in the German-speaking countries with thirteen women and thirty-seven men mentioned (Goethe Institut n.d.). 
fragmentation of the texts, a creation of blank spaces that challenge the audience to occupy these spaces themselves, thus allowing for new ways of perception and abandoning practised patterns.

Since binary oppositions eventually permeate the whole concept, Jelinek differentiates between primary and secondary drama, major and minor drama, original and copy or she cites the dichotomies inscribed in the primary dramas such as those of woman/man, private/public, up/down, inside/outside, life/death in order to finally penetrate them as a third element, to make the supposed obviousness of these distinctions brittle and to create growths on these breaking points that make that what was made invisible and excluded re-emerge on the visible surface. Even the information on a possible realization of the texts described in this essay refers to the excess, to the refusal to create meaning through permanent overproduction and to the generation of "language waste" (Schößler and Bähr 2009: 18). This lets the texts repeatedly pass into a noise seemingly devoid of meaning, which also applies to the primary dramas in the moment of staging, inscribing the disturbance as ever-present possibilities in the dramas.

By the principle of addition, the concept of secondary drama undermines the reduction of complexity as it occurs in the production of social self-images and norms (Koch and Nanz in this volume: 3). The method pursued by secondary drama makes us aware of the (usually hidden) exclusion of plurality in favor of unambiguity. Any apparent certainty and clarity is broken up by the concept, the texts work with constantly conflicting voices, they cite supposedly verified categories, in order to eventually and even more certainly cut the ground under the recipients' feet. Secondary drama breaks with the established forms of memory and of remembrance culture that draw a distinction between what is memorable or significant and not memorable or insignificant and that understand history as the history of the rulers, refusing to create meanings in the sense of assessable entities. Secondary drama combines canonized literature with everyday banalities, thus following a non-hierarchical principle of equal juxtaposition. In the mixture of identity-establishing canon and perishable textual material, the decay is inscribed in what remains, yet due to this strategy, the volatile aspects might conversely participate in it.

In the meantime, the notion of secondary drama begins to establish itself not only in the arts section and in theatres but also in the research on Jelinek as a description of the intertextual method and of Jelinek's appending to canonized theatrical texts. Secondary drama and parasitic drama (Parasitärdrama) - a term Jelinek introduced shortly after publishing this essay as a category describing her plays - are often used interchangeably (Jelinek 2011). When applying the concept of secondary drama to all other texts of the author, we run the risk of overlooking the specific disturbance potential and the rich forms of the aesthet- 
ics of disturbance this concept comprises. Jelinek herself claims she does not want to write secondary dramas anymore and inhibits partially that the concept should be applied in the staging of other theatrical texts. ${ }^{10}$ This suggests that secondary drama is not intended to give rise to a new "genre;" it manifests itself as a single event disturbance in order to develop a potential to produce irritation and disagreement in the longer term.

\section{Works Cited}

Behrendt, Barbara (2013) Vorspiel: Die Autorin Elfriede Jelinek. <http://www.theaterheute.de/ blog/muelheimstuecke/vorspiel-die-autorin-elfriede-jelinek> (accessed 15 July 2014).

Deutscher Bühnenverein (1991-2013) Wer spielte was? Werkstatistik Deutschland, Österreich, Schweiz (Bensheim: Mykene Verlag).

Goethe Institut (n.d.) 50 Directors Working at German Theatres. <http://www.goethe.de/kue/ the/reg/reg/enindex.htm> (accessed 6 March 2016)

Haß, Ulrike and Monika Meister (2015) “"Wie ist es möglich, Theater ausschließlich mit Texten aufzustören?" E-Mailwechsel zwischen Ulrike Haß und Monika Meister," in "Postdramatik." Reflexion und Revision, ed. Pia Janke and Teresa Kovacs (Diskurse Kontexte Impulse. Publikationen des Elfriede Jelinek-Forschungszentrums 11), 112-118.

Jelinek, Elfriede (1984) "Ich schlage sozusagen mit der Axt drein," TheaterZeitSchrift 7, $14-16$.

Jelinek, Elfriede (2005) "Sprech-Wut," in Literaturen special 1.2, 12-15.

Jelinek, Elfriede (2010) Anmerkung zum Sekundärdrama <http://www.elfriedejelinek.com/fse kundaer.htm> (accessed 17 August 2017).

Jelinek, Elfriede (2011) Das Parasitärdrama <http://www.elfriedejelinek.com/ fparasitaer.htm> (accessed 17 August 2017).

Jelinek, Elfriede (2012) Grußworte nach Japan <http://www.elfriedejelinek.com/\%20fjapanfes tival.htm> (accessed 17 August 2017).

Jürs-Munby, Karen and Artur Pelka (2015) “'Postdramatik?’ Zur aktuellen Forschung mit Blick auf Elfriede Jelinek," in "Postdramatik." Reflexion und Revision, ed. Pia Janke and Teresa Kovacs (Diskurse Kontexte Impulse. Publikationen des Elfriede JelinekForschungszentrums 11), $17-32$.

Kehlmann, Daniel (2011) Die Lichtprobe <http://landversand.salzburg.gv.at/WebRoot/Store/ Shops/Landversand/5252/A3F4/B2AD/9DCB/3785/4DEB/AE3E/249B/kehlmann09.pdf> (accessed 16 June 2015).

Koberg, Roland (2012) "Die Bühne ist ein klaustrophobischer Raum. Die Schriftstellerin Elfriede Jelinek im E-Mail-Austausch mit dem Dramaturgen Roland Koberg," in Programmheft des Schauspielhauses Zürich zu Faust 1-3.

10 See for example Die Schutzbefohlenen at the Schauspiel Leipzig, directed by Enrico Lübbe, where she forbade the combination with Aeschylus's The Suppliants in the form of a secondary drama and only allowed a succession of both texts. 
Kovacs, Teresa (2016) Drama als Störung. Elfriede Jelineks Konzept des Sekundärdramas

(Bielefeld: transcript).

Lehmann, Hans-Thies (1991) Theater und Mythos (Stuttgart: Metzler).

N.N. (2009) "Was heißt hier Kunst?," Theater heute 6, 4-5.

Schabert, Ina and Barbara Schaff (1994) "Autorschaft. Genus und Genie in der Zeit um 1800," in Geschlechterdifferenz \& Literatur 1, ed. Ina Schabert and Barbara Schaff (Berlin: Erich Schmidt).

Schleef, Einar (1997) Droge Faust Parsifal (Frankfurt a.M.: Suhrkamp).

Schößler, Franziska and Christina Bähr (2009) "Die Entdeckung der 'Wirklichkeit'. Ökonomie, Politik und Soziales im zeitgenössischen Theater," in Ökonomie im Theater der

Gegenwart, ed. Franziska Schößler and Christina Bähr (Bielefeld: transcript), 9-20.

Serres, Michel (1982) The Parasite (Baltimore: John Hopkins University Press).

Stegemann, Bernd (2014) Kritik des Theaters (Berlin: Theater der Zeit).

Szondi, Peter (1983) "Theory of the Modern Drama, Parts I-II," in boundary 2 11.3, 191-230.

Tigges, Stefan (ed.) (2008) Dramatische Transformationen (Bielefeld: transcript).

Turrini, Peter (2011) Rede zur Verleihung des Nestroy-Preises $2011<$ http://www.profil.at/ home/peter-turrini-rede-verleihung-nestroy-preises-2011-345629> (accessed 16 June 2015). 